\title{
Motivation towards Inbound Tourism: A Study of Middle East Tourist
}

\section{Dhanik Puspita Sari}

\author{
Sekolah Tinggi Pariwisata Bogor
}

Corresponding author: dhanik_puspitasari@yahoo.com

\section{ARTICLE INFO}

Received

15 July 2019

Accepted

06 September 2019

Available online

30 September 2019

\section{ABSTRACT}

This research discusses the motivation of Middle East Tourists who come and visit Pucak areas in West Java. Puncak is an area that has a cool climate with beautiful natural scenery located not far from Jakarta, the capital city of Indonesia. Middle East tourists are a potential market for Indonesian tourism. The ampunt of the expenditure is highest compared to other tourists who visiting Indonesia. And certainly for the locals it give impacts on the economy of the surrounding community. This study uses a descriptive quantitative approach, using questionnaires and literature studies in data collection and data analysis using linear regression. Data was collected from 100 inbound Middle East tourists who travel and visited Puncak Area. The Pearson correlation was used to find the relationship between push and pull factor motivation towards their visiting decision. ANOVA and T Test used to examine the indicators. The result shows that push and pull motivation influenced the visiting decision of inbound tourism, partially and simultaneously. Relaxation got the highest score in push motivation, meanwhile the environment and weather conditions dimension got the highest score on pull motivation.

Keywords: Tourist Motivation, Push and Pull Motivation, Inbound Tourism, Puncak.

\section{INTRODUCTION}

\section{Background}

Tourism is one industry that continues to grow from year to year. The growth of tourism as a social phenomenon and as an economic endeavor has continued to advance and become one of the most dominant sectors in almost every country as a way to bring in profits in the form of foreign exchange for the country. In Indonesia, it is the largest sector for the country foreign exchange contributor. It is in the second ranks with Rp.190 trillion, after the palm oil contribution (Antariksa, 
2017). Increasing tourism destinations and investments make tourism become a key factor in export revenues, job creation, business development and infrastructure (UNWTO, 2016).

Bogor Regency is located not far from Jakarta, the center of state government. Natural beauty and freshness of climate and weather make this Regency visited a lot by both domestic and foreign tourists. Mostly, Middle East tourist dominate this area, especially in Puncak Area. We can easily find them there doing various activities. In 2013 Middle Eastern tourists who came and visited Indonesia is about 187,439, and increased in 2014 to 216,313 (Kementrian Pariwisata dan Ekonomi Kreatif). In 2016, if we compare to others foreign tourist, their expenditure is the highest. It's about USD 1.918,18, its highest compare to Oceania (USD 1.539, 21) and Europe (USD 1.538, 66) (Passenger Exit Survey (PES) Kemenpar, 2016, makes them become a potential market for Indonesian tourism.

Many things can encourage tourist to decide on choosing their destinations (Sari, 2017). A lot of reasons and motivation that make this Middle East tourist comes or visit Puncak area, and we call it as motivation. Motivation is an urge or turmoil that arises from within human beings to fulfill their various needs in http://ojs.unud.ac.id/index.php/eot accordance with their respective desires (Afin Murtie, 2012: 63). Needs will encourage the emergence of motivation to make efforts to maximize its energy in order to satisfy itself (Pritchard \& Ashwood, 2008), this reasons for someone who has a strong desire, makes distance in geography not become barrier because for them, desired must be fulfilled.

Needs will move become wants, because there is awareness created from effected marketing efforts and Traveling has become a fundamental thing that is felt always wanted to be fulfilled since traveling is a basic human need and want (Hermantoro, 2015). Tourist motivation influenced by push factor and pull factor. Push factor is factors which come from inside tourist itself, while pull factor comes from the outside, usually in the form of the destination condition to be visited (Sudaryanti et al, 2015). The intrinsic motivation refers to the enjoyable and attractiveness of an activity, while the extrinsic motivation refers to doing activity (Kuhn et.at, 2019). Every tourist must have a different motivation. The difference of tourist attractions will distinguish their motivation. In order to gather more Middle Eastern tourists to come to visit Indonesia, especially in the Puncak area, the host should be adjusted with their visiting motivation. 


\section{Research Objectives}

There are many middle-east tourists visiting Puncak area with a huge amount of money. It's around 1.5 billion per day, where $80 \%$ of it is spent in Warung Kaleng, making this tourists a potential market to develop, and in the other hand, Indonesian government actually targets the number of Middle East tourists visiting Indonesia as many as 300,000 tourist. In determining their decision, in this case will they visit a destination or not, travelling or not will depend on the motivation background. Motivation is an encouragement. It could rise from their self because of their need and wants or it could rise from outside because something that interests and attract their intention. Therefore this research was conducted to find out whether there was a significant influence of push and pull motivators on visiting decisions made. Beside, this research is also expected to show a complete picture of what drives and attracts them to come to visit the Puncak. And hopefully that the host could provide anything needed in order to fulfilling their expectation so they can get a good experience and are have willingness to keep coming back.

http://ojs.unud.ac.id/index.php/eot

\section{LITELATURE REVIEW}

\section{Inbound Tourism}

Inbound tourism also similar with incoming tourism. It means travellers arriving in different countries from their own. According to the World Tourism Organization the inbound tourism is the activities of the visitor travelling to a place outside his usual environment for not more than one consecutive year and not less than 24 hours. The travel is for leisure, business and not for permeant working and gainingmoney (http://www.oicstatcom.org, 2018). It also defined as comprising the activities of non-residents travelling to a given country that is outside their usual environment, and staying there no longer than 12 consecutive months for leisure, business or other (corresponding) purpose (https://www.stat.fi, 2018). In a simple it is non- resident traveling in the given country. A tourist comes outside the country.

\section{Motivation}

Motivation comes from Latin words "movore", which means motion or drive to move (Prawira: 2014). Motivation in Indonesian, comes from the word motive which means the effort that drives someone to do something. Motives can be said to be the driving force of the subject to perform certain activities in order to 
achieve goals (Eschols \& Shadily, 2003). Motivation is the reason of behavior to cause a person to act in a certain way or to stimulate interest in inducing a person to act (Ali-knight: 2000). identification of motivation in the first step towards generating destination plans because this explain why tourist make a trip and type of experience, destination or activity they want Kim, (Lee \& Klenosky, 2003). In short, travel motivation can be simplified by the question why people travel (Dann, 1977).

Several studies have been done in terms of the motivation to travel, so there are several approaches to classification of this tourism motivation or travel motivation can be divided into two approaches namely push factor and pull factor (Dann, 1971) since it is effective and easy to use (Prayag \& Hosany, 2014). Various studies also have been carried out by experts such as Cohen (1972) Crompton, (1979), Dann (1977), Jang \& Cai (2002), Kim et al. ( 2007), they found the similarity that there are two main strengths in motivation, namely push motivation and pull motivation. Push motivation tend to the desire of tourists to leave, while pull motivation is more to the choice of destination to be visited. Based on those explanation, it can be concluded that motivation is everything that as a background or encourages someone to do something, and this motivation is divided into two: push motivation and pull motivation.

\section{Push Motivation}

Travel done by someone not just happened instantly. The driving factor is the physical strength or form of a person such as social interaction, the desire for escape, adventure, relaxation, selfexploration (Dann, 1977) and (Klenosky, 2002). Push factors have been conceptualized as motivational factors or needs that arise due to a disequilibrium or tension in the motivational system (Kim et al, 2003 ) which can be said that the pulling factor is a need that arises because of an imbalance or tension in a person, an in simple can be summarized as "weather to go or will someone leave or not" (Klenosky 2002).

There's a lot of research referring to push motivation. They also expressed several dimensions related to push motivation, among others as Anomie, ego enhancement (Dann, 1977), Escape, selfexploration and interviews evaluation, relaxation, prestige, regression, enhancement of kinship (Crompton, 1979), Escape, Novelty, Prestige, enhancement of kindship relationship, relaxation/hobbies (Yuan \& McDonald, 1990), Cultural e-ISSN: 2407-392X. p-ISSN: 2541-0857 
experiences, scape, re-experiencing family, sports, prestige (Turnbull and Uysal, 1995), Knowledge/intellectual, Kindship/ social interaction novelty/adventure, entertainment/prestige, sports, escape/rest (Oh, Uysal \& Weaver, 1995). Relaxation, knowledge, adventure, travel bragging, family, sports (Cha, Mc Cleary \& Uysal, 1995), Sports/activity seeker, novelty seekers, urban-life seekers, beach/resort seekers (Bologu \& Uysal, 1996), Escape motives, relaxation, prestige, family and friend togetherness, knowledge, sport motivation, adventure, enjoying natural resources, desire for sex, motivations of alcoholic consumption (Alghamdi, 2007), Escape, visiting family and friend, quality of hotels, friendliness od people, re-enactment or pervious enjoyable experiences (Prayag \& Ryan, 2011), Get experience in foreign land, learn new culture, relax, learn new thing, interested in culture, escape from same daily live, enjoy activities, adventure, interested in natural resources, find parter (Yiamjanya and Wongleedee, 2014), Competition, spiritual refreshment, novelty seeking, contribution and sharing, bire-related, relationship building (Chen \& Chen, 2015), Risk taking, challenge, catharsis, recognition, creativity, physical setting (Caber \& Albayrak, 2016).
Based on several theories above, this study is using the motifation theory of Middle East tourists (Alghamdi, 2007), because it felt in accordance with the type of tourists studied, which is composed from: 1) escape motives, 2) relaxation, 3) prestige, 4) family and friends togetherness, 5) Knowledge, 6) sports motivation, 7) adventure, 8) enjoying natural resources, 9) desire for sex, 10) Alcoholic consumptions.

\section{Pull Motivation}

Besides push factor, there also a push factor in doing traveling. Pull factor is a form of specific attributes (Wibisono, 2013). Various pull factors should be owned by a destination in order to fulfil the needs and wants of the tourist. The pull factor comes more from the treat or attraction for tourist to come and visit. Attraction is very important factors for a destination (Sari, 2017). A forms of attractive factors can be said as the environmental conditions that make a person interested in coming to a destination such as sunshine, historical monuments, sports facilities and cheap air tickets (Dann, 1977). In summary, the pull factor can be said as "where to go" (Kenosky, 2002). Attractive factors related to tourist attractions in the area or tourist destination, attractions can also be in the form of fame (Fandeli, 1995). e-ISSN: 2407-392X. p-ISSN: 2541-0857 
Encouragement to visit to visit friends or family and the ongoing sports competition is also an attraction. Pull Factor is considered useful in explaining the actual choice of destination (Seebaluck, Naidoo, Munhurrun \& Mungur, 2013)

Tourism activities to visit tourism objects include visiting, seeing and feeling the beauty of nature with its various variations, climatic conditions, culture and attractions, history and legends, ethnicity with its tribal nature, accessibility, namely ease of achievement (Spillane, 1997). The essence of the various definitions and statements above is that the pull factor is everything that is owned by a particular place that can attract tourists to come and visit in order to meet the needs and desires that arise from within them.

The simplest, pull factor dimension consist of Novelty, education reason (Crompton, 1979), where further research is also found that Budget, culture and history, wilderness, ease of travel, cosmopolitan environment, facilities, hunting into the pull factor category (Yuan \& McDonald, 1990). Besides that, Entertainment/Resort,outdoors/

nature,heritage/ culture, rural/inexpensive (Uyasal \& Jurowski, 1994) followed by Heritage/culture, City enclave, comfort/relaxation, beach resort, outdoor resources, rural and inexpensive in its development as a dimension from pull http://ojs.unud.ac.id/index.php/eot motivation (Turnbull \& Uysal, 1995). Outbound tourism motivation for Middle East tourist for pull factor consist of Historical attraction, environment and weather attractions, expenditure and low cost factors, sports and outdoor activities, sex tourism, alcohol attractions (Alghamdani, 2007). The other researchers found that pull factor dimension are Friendliness and hospitality of people, the family oriented, romantic place, $3 \mathrm{~S}$ it is sea, sun and Sand (Prayag \& Ryan, 2011), Facilities and infrastructure, professional guiders, local culture and traditions, avian resources (Chen \& Chen, 2015), Novelty seeking, tourism infrastructure, sports and leisure activity, reclusiveness (Caber and Albayrak, 2016). In this study the pull motivation used is the theory used at the outbound tourist motivation of Middle East tourists (Alghamdani, 2007), where if they travel to Indonesia, then they are inbound tourism tourists.

\section{Visiting Decision}

Visiting decisions are decisions taken by a person or group to travel to certain tourist destinations for vacation / recreation purposes, improve self-quality, study historic sites and find out the uniqueness of an area, to enjoy a tourist attraction in a destination visited within a certain period. A person's decision to visit is inseparable from consumer behavior 
which in this case is the tourists themselves. Consumer behaviour is the process involved when individuals or groups select, purchase, use, or dispose of products, services, ideas or experiences to satisfy needs and wants (Swarbrooke \& Horner, 2007). Consumer behaviour refers to the buying behaviour of individuals and households who buy goods and services for personal consumption (Kotler and Armstrong, 2009). The statement means that consumer behaviour is a process from the beginning to the downstream carried out by someone in order to meet their needs and desires. That process will influence will someone travelling or not. In the world of marketing tourist visits can also mean the same as the purchase decision (Putra et al. 2015).

Tourist decision to visit is similar with consumer purchase decision (Jalilvand and Samiei, 2012). Visiting decision is a process where a visitor evaluates and chooses one alternative that is needed based on certain considerations. In the world of tourism, purchasing decisions are assumed to be a visiting decision so theories about purchasing decisions are used also in visiting decisions (Wandari et al, 2014). In a visiting decision process, tourists need several alternative of destination and require an effort from tourist attractions to get to tourists with something special in order to make people comes. The company must also have the power and role to design and provide stimulants to influence someone to come. The dynamic process of interaction between buyers and the environment (Hollensen, 2010). Some important things are psychological variables that influence in consumer decision making encompass needs, perception, memory and attitudes. Personal consumer characteristics such as demographic and lifestyle variables. The influence of psychological factors is needs, perception, memory and attitude (Hollensen, 2010).

In this case, purchase decision referring to the visit decision in a tourism place, and tourist will go through five stages namely the introduction of problems, information search, alternative evaluation and purchasing decisions (Kotler and Keller, 2014). The decision to come and visit a destination does not just come suddenly into one's mind. It can be ascertained that in any decision made, there are always certain considerations or factors behind it. Tourist visiting decisions are influenced by push factors and pull factors (Crompton in Kozak and Decrop, 2009).These push and pull factors are internal and external factors that motivate 
tourists to make decisions in traveling (Hermansyah and Waluya 2012).

\section{METHODOLOGY OF DATA ANALYSIS}

This research is located in Puncak area, especially in Warung Kaleng West Java, Indonesia. This study use quantitative method and data analysis using linear regression. Data was collected from 100 inbound Middle East tourists who travel and visited Puncak Area. The data includes: information gathered from questionnaires, statistics data from several sources in order to provide a holistic description related to the tourist motivation (push and pull motivation) towards their visiting decision, and also includes literature studies to support it to be more convincing scientifically.

Primary data is gathered directly from Middle East Tourist who comes and visit Puncak especially Warung Kaleng area, while secondary data is gathered trough study literature, previous related study and also from third party which has correlation with this research like tourism and culture bureau of Bogor regency and Central Bureau of Statistics of Indonesia. The hypothesis of this research, is there an influence motivation towards Middle East travel decision. Data is collected with the use of questionnaire using Likert scale http://ojs.unud.ac.id/index.php/eot from Scale 1 = Disagree Strongly to scale 5 = Agree strongly. Data analysis was done through statistical frequency and mean or average in a tabular form. The Pearson correlation was also used to find the relationship between push and pull factor motivation towards their visiting decision. ANOVA and $\mathrm{T}$ Test used to examine the indicators

\section{DISCUSSION AND RESULT}

The description of the data contained in this study include the general description of respondents based on gender, age, national origin, marital status, latest education, costs spent and the number of visits in the last three years to Puncak. The details of the general description obtained are as follows: 
Table 1. Tourism Demographic Profile

\begin{tabular}{|c|c|c|c|}
\hline & Age & $\begin{array}{c}\text { Frequ } \\
\text { ency }\end{array}$ & $\begin{array}{c}\text { Perc } \\
\text { ent }\end{array}$ \\
\hline \multirow{3}{*}{ Age } & $18-35$ & 61 & 61.0 \\
\hline & $36-50$ & 33 & 33.0 \\
\hline & $>50$ & 6 & 6.0 \\
\hline \multirow{9}{*}{ Origin } & Saudi Arabia & 53 & 53.0 \\
\hline & Egypt & 8 & 8.0 \\
\hline & Oman & 4 & 4.0 \\
\hline & Yemen & 2 & 2.0 \\
\hline & $\begin{array}{l}\text { Arab } \\
\text { Emirates }\end{array}$ & 15 & 15.0 \\
\hline & Kuwait & 5 & 5.0 \\
\hline & Bahrain & 2 & 2.0 \\
\hline & Qatar & 2 & 2.0 \\
\hline & Others & 9 & 9.0 \\
\hline \multirow{2}{*}{$\begin{array}{l}\text { Marital } \\
\text { Status }\end{array}$} & Single & 63 & 63.0 \\
\hline & Married & 37 & 37.0 \\
\hline \multirow{5}{*}{$\begin{array}{l}\text { Educationa } \\
1 \\
\text { Backgroun } \\
\text { d }\end{array}$} & $\begin{array}{l}\text { Junior High } \\
\text { School }\end{array}$ & 5 & 5.0 \\
\hline & $\begin{array}{l}\text { Senior High } \\
\text { School }\end{array}$ & 29 & 29.0 \\
\hline & $\begin{array}{l}\text { Undergradua } \\
\text { te }\end{array}$ & 47 & 47.0 \\
\hline & $>$ & & 19.0 \\
\hline & Postgraduate & 19 & \\
\hline \multirow{3}{*}{$\begin{array}{l}\text { Spending } \\
\text { Amount }\end{array}$} & $\begin{array}{l}\mathrm{Rp} \\
1.000 .000- \\
\mathrm{Rp} 10.000 .00 \\
0\end{array}$ & 13 & 13.0 \\
\hline & $\begin{array}{l}\text { Rp } \\
10.000 .000- \\
\text { Rp20.000.00 } \\
0\end{array}$ & 30 & 30.0 \\
\hline & $\begin{array}{l}>\text { Rp. } \\
20.000 .000,-\end{array}$ & 57 & 57.0 \\
\hline \multirow{4}{*}{$\begin{array}{l}\text { Visitation } \\
\text { within } 3 \\
\text { years }\end{array}$} & 1 times & 33 & 33.0 \\
\hline & $2-3$ times & 37 & 37.0 \\
\hline & $4-5$ times & 8 & 8.0 \\
\hline & $>5$ times & 22 & 22.0 \\
\hline
\end{tabular}

Source : Research Data, 2018

Table 1 reveals that the demography categorized into six, namely age, origin, marital status, educational http://ojs.unud.ac.id/index.php/eot background, spending amount and visitations within three years. The table shows that $61 \%$ of the respondents is between 18-35 years old, it is a productive age, and they has an independent income and always wants to try something new. $53 \%$ comes from Saudi Arabia since it has a fairly hot climate, as well as a deteriorating natural state, no wonder a lot of Middle East tourists from this country come and visit Puncak areas, especially to Warung Kaleng which has very different climate compare to their origin. They are looking for something green, cool and beautiful and also supported by the living cost that suits them.

It's about $63 \%$ marital status of the respondents is single. Due to a lot of tourist age between 18-35 years old, most of them are single and mostly come to visit their friends and not their families. For educational background, $47 \%$ of the respondent graduated from undergraduate programme and for the spending, 57\% spend their money in this area for more than Rp. 20,000,000,- per visit. This is possible because most of these tourists live in a fairly long period of time. Usually they stay for a few weeks, even many are up to months and most of the respondents visiting this place around 2-3 times in recent last three years for about $37 \%$. 
Based on the data above, it can concluded that almost every year these tourists come and visit this place. This is possible because of several reasons, namely the number of available holidays is quite a lot, weather conditions or climates are very cool which is very different from their home regions and the costs or expenses are felt in accordance with their capabilities so they can often visit this place. Beside the description of the demography, this study also find the specific motivation of the inbound tourist as follows:

Table 2. Descriptive Statistics of Middle East Tourist

\begin{tabular}{|c|c|c|}
\hline Variable & Dimension & Mean \\
\hline \multirow{10}{*}{$\begin{array}{l}\text { Push } \\
\text { Motivation }\end{array}$} & Escape Motives & 4.12 \\
\hline & Relaxation & 4.28 \\
\hline & Prestige & 3.38 \\
\hline & $\begin{array}{l}\text { Family and Friends } \\
\text { Togetherness }\end{array}$ & 3.98 \\
\hline & Knowledge & 3.82 \\
\hline & Sport & 3.81 \\
\hline & Adventure & 3.91 \\
\hline & $\begin{array}{l}\text { Enjoying Natural } \\
\text { Resources }\end{array}$ & 4.13 \\
\hline & Desire for Sex & 3.63 \\
\hline & Alcoholic Consumption & 3.51 \\
\hline \multirow{6}{*}{$\begin{array}{l}\text { Pull } \\
\text { Motivation }\end{array}$} & Historical Attraction & 3.63 \\
\hline & $\begin{array}{l}\text { Environment and Weather } \\
\text { Conditions }\end{array}$ & 3.99 \\
\hline & $\begin{array}{l}\text { Expenditure and Low Cost } \\
\text { Factors }\end{array}$ & 3.98 \\
\hline & $\begin{array}{l}\text { Sports and Outdoor } \\
\text { Activities }\end{array}$ & 3.96 \\
\hline & Sex Tourism & 3.80 \\
\hline & Alcohol Attraction & 3.41 \\
\hline \multirow{4}{*}{$\begin{array}{l}\text { Travel } \\
\text { Decision }\end{array}$} & Problem identification & 3.90 \\
\hline & Information Search & 3.61 \\
\hline & Alternative Evaluation & 3.87 \\
\hline & Tourism Decision & 3.82 \\
\hline
\end{tabular}

Source: Research Data, 2018
The above table divided variable into three categories, they are push motivation, pull motivation and travel motivation. Push motivation, with the highest value is relaxation dimension with 4.28 and the lowest is the alcoholic consumption dimensions with 3.51. Pull motivation with the highest value is environment and weather condition with 3.99, and the lowest is alcohol attraction dimensions with 3.41. The travel decision highest score is in problem identification with 3.90 and the lowest is information search dimension with 3.61 .

Several dimensions in push motivation get more than 4 (in score). They are escape, relaxation and followed by enjoying natural resources. The same research results found in Thailand and their research results shows that the best score range (above 4) is escaping from same daily life factors, enjoying activities and relax in foreign land (Yiamjanya and Wongleedee, 2014) it also became the most dominant motives for family to travel (Ingkadijaya, 2018). A study in South Africa, stated that there was an influence between the push motivation for the decision of an individual to visit (Giddy and Webb, 2016). As for some factors with the highest second score in the item under push motivation is enjoying natural beauty and novelty. The previous research 
in examining the motivation of tourists found that in push motivation, the factor of enjoyment $(51.5 \%)$ and being close to nature $(39.6 \%)$ became a fairly high value (Caber and Albayrak, 2016) .

Based on the result from this study, as well as the results obtained from the previous studies, it can be concluded that the relaxation factors, escape from the routine, and the desire to enjoy the beauty of nature are the factors most desired by tourists, and it can be said that these factors are the most encouraging tourists to visit a place or tourist destination. And for the pull motivation in this study, the highest dimensions are environment and weather condition, expenditure and low cost factor, sport and outdoor activities. The similar research also found that climate or weather condition is the main factor in pull motivation for $48.5 \%$ (Caber and Albayrak, 2016), and gain the highest score is pull environment for 3.83 (Giddy and Webb (2016). The other research also found that the beauty of the nature got the highest score with $95 \%$ and respondents stated that it is the most important factor for them. Beside natural beauty, the climate also become the main factor for pull motivation for about $92 \%$. The results of research conducted in this study and compared with some previous studies, it can be concluded that indeed the most interesting factor or motivation for makes tourist to come and visit is because of the climate or weather, activities, and the natural beauty.

To find deeper related to the influence between tourist motivation (in this case is push and pull motivation) towards Middle East tourist visiting decision could be found below:

Table 3. Hypothesis Testing Result.

\begin{tabular}{|c|c|c|c|}
\hline Hypothesis & Statement & Score & Remarks \\
\hline H1 & $\begin{array}{l}\text { Push } \\
\text { Motivation } \\
\text { Significantly } \\
\text { Influence } \\
\text { tourist visiting } \\
\text { decision }\end{array}$ & $\begin{array}{l}\mathrm{t}=2.865 \\
\mathrm{Sig}= \\
0.000\end{array}$ & $\begin{array}{l}\mathrm{H}_{0} \text { rejected } \\
\mathrm{H}_{1} \text { accepted }\end{array}$ \\
\hline $\mathrm{H} 2$ & $\begin{array}{l}\text { Pull } \\
\text { Motivation } \\
\text { Significantly } \\
\text { Influence } \\
\text { tourist visiting } \\
\text { decision } \\
\end{array}$ & $\begin{array}{l}t=1.590 \\
\text { Sig }= \\
0.000\end{array}$ & $\begin{array}{l}\mathrm{H}_{0} \text { rejected } \\
\mathrm{H}_{2} \text { accepted }\end{array}$ \\
\hline $\mathrm{H} 3$ & $\begin{array}{l}\text { Push and Pull } \\
\text { Motivation } \\
\text { Significantly } \\
\text { Influence } \\
\text { tourist visiting } \\
\text { decision }\end{array}$ & $\begin{array}{l}F= \\
35.506 \\
\text { Sig }= \\
0.000\end{array}$ & $\begin{array}{l}\mathrm{H}_{0} \text { rejected } \\
\mathrm{H}_{3} \text { accepted }\end{array}$ \\
\hline
\end{tabular}

Source: Research Data, 2018

The above table is the hypothesis testing result that shows all hypothesis is accepted. It is the recapitulation of t-test and ANOVA in this study. To describe all test in details, the following table could represent the result: 
Table 4. T-test for Push Motivation

\begin{tabular}{|c|c|c|c|c|c|c|c|c|}
\hline \multicolumn{9}{|c|}{ Coefficients } \\
\hline & \multirow[t]{2}{*}{ Model } & $\begin{array}{r}\text { Unstar } \\
\text { Coef }\end{array}$ & $\begin{array}{l}\text { dardized } \\
\text { icients }\end{array}$ & \multirow{2}{*}{$\begin{array}{c}\begin{array}{c}\text { Standardize } \\
\mathrm{d}\end{array} \\
\text { Coefficients }\end{array}$} & \multirow[t]{2}{*}{$\mathrm{t}$} & \multirow[t]{2}{*}{ Sig. } & \multicolumn{2}{|c|}{$\begin{array}{c}\text { Collinearity } \\
\text { Statistics }\end{array}$} \\
\hline & & $\bar{B}$ & Std. Error & & & & Tolerance & VIF \\
\hline & (Constant) & 2.450 & 1.541 & & 1.590 & .115 & & \\
\hline 1 & $\begin{array}{l}\text { Push } \\
\text { Motivation }\end{array}$ & .331 & .040 & .645 & 8.357 & .000 & 1.000 & 1.000 \\
\hline
\end{tabular}

a. Dependent Variable: Visiting Decision

Source: Research Data, 2018

Based on the t-test table above, could be shown that the significance value of push motivation is $0.00<0.05$ which indicate that the hypothesis is accepted. It also strengthen by the result of $t_{\text {count }}>t_{\text {table, }}$, which is $8.357>1,984$. It means that the push motivation significantly influence the tourist visiting decision.

Table 5. T-test for Pull Motivation

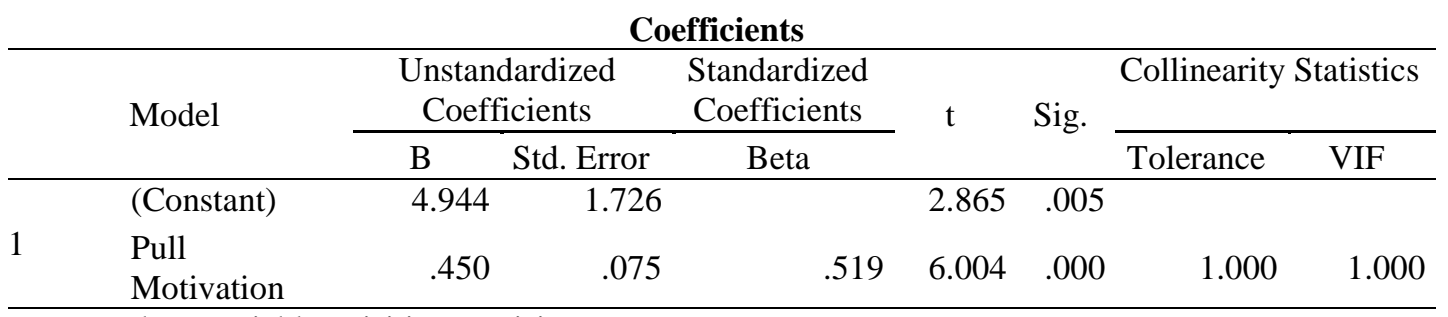

a. Dependent Variable: Visiting Decision

Source: Research Data, 2018

The table above shows that the significance value of pull motivation is $0.00<0.05$ which indicate that the hypothesis is accepted. It also strengthen by the result of $t_{\text {count }}>t_{\text {table, }}$, which is 6.004 $>1,984$. It means that the pull motivation also significantly influence the tourist visiting decision.

The above table shows the significance value of push motivation and pull motivation simultaneously is $0.00<0.05$ which indicates that this hypothesis is accepted, which means push and pull motivation has a significant influence on visiting decisions. This is also strengthened by the acquisition of $F_{\text {count }}>F_{\text {table, }}$, which is $35.506>3.09$. Shows that the push motivation and pull motivation have a positive and unidirectional relationship towards tourist visiting decisions.
ANOVA ${ }^{a}$

\begin{tabular}{|c|c|c|c|c|c|}
\hline Model & $\begin{array}{c}\text { Sum of } \\
\text { Squares }\end{array}$ & df & $\begin{array}{c}\text { Mean } \\
\text { Square }\end{array}$ & $\mathrm{F}$ & Sig. \\
\hline Regression & 342.356 & 2 & 171.178 & 35.506 & $.000^{\mathrm{b}}$ \\
\hline Residual & 467.644 & 97 & 4.821 & & \\
\hline Total & 810.000 & 99 & & & \\
\hline
\end{tabular}

Source: Research Data, 2018 


\section{CONCLUSION}

The Middle East tourist motivation and their visiting decision in Puncak area was investigated. The study made use of questionnaires to gather relevant information for the study. Convince sampling method was used to select 100 respondents. Data collected was analyzed using frequency count, mean (average) and double regression linear. Table 1 shows most of the respondents is between 18-35 years old (61\%), from Saudi Arabia (53\%), single (63\%), undergraduate (47\%), spend more than RP. 20,000,000,$(57 \%)$ and visiting this place around 2-3 times in recent last three years $(37 \%)$. Table 2 shows that the highest score for push motivation is relaxation (4.28), the highest score of pull motivation is environmental and weather condition (3.99), and for the traveling decision, the highest score is problem identification (3.90). Table 3 shows that there is an influence between push and pull motivation towards their traveling decision. While the push factor is the most significant is influencing the travel decision.

\section{RECOMENDATION}

In order to increase the number of Middle Eastern tourist visitation, it would be better to focus on several points, such as:

1. Providing facilities and amenities for nature-based relaxation activities such as:

a. Providing relaxation facilities at the hotel such as spa or saunas with direct natural view.

b. Activation of agro tourism or wellness tourism activities around the peak area due to the large number of springs in the surrounding area that can be developed as wellness tourism such as Ciburial springs, where the local government can cooperate with the private sector in terms of funding for the development of this types of tourism, on the other hand the government also could give permission to manage the existing natural resources while sticking to the environmental balance.

c. Maintain cleanliness of the surrounding area by providing a good trash can within a certain distance.

d. The number of illegals street seller or restaurants located on the edge or side of the mountainside disturb the view, and make the area feel e-ISSN: 2407-392X. p-ISSN: 2541-0857 
chaotic and slum. They should be given a place that can accommodate them to trade and not make slums around the natural landscape.

\section{Promotion strategy}

a. Making promotional tools in which there is a visual beauty of the peak area, supported by images of tourists who are relaxed and enjoy the local beauty.

3. Government and private sector for development

a. Exploring nature with no exaggeration and does not change or damage the existing ecosystem.

b. Increase the involvement of the local community by conducting training related to tourism business violations such as tour guide training, training in the provision of food in terms of quality, packaging, hygiene, as well as providing services to tourists. Providing foreign language training needed to be able to communicate with tourists, namely by training in Arabic and English.

c. Providing training on the management of plantation resources (both fruits and vegetables) to be made into something interesting for consumption and sale. d. Collaborating with entrepreneurs who have considerable capital to be able to assist the community in terms of providing funds or in terms of promotional activities in promoting food products or handicrafts that are ready for sale.

\section{ACKNOWLEDGMENT}

I would like to express my appreciation to Bogor School of Tourism (STP Bogor) for the support and also to Trisakti School of Tourism (STP Trisakti) which encouraged me to complete this research through field research in postgraduate program in tourism department.

\section{REFERENCES}

Afin Murtie, (2012). Menciptakan SDM Berkuwalitas, PT. Gelora Aksara Pratama. Jakarta.

Alghamdi, Abdulraheem. (2007)., Explicit and Implicit Motivation Towards Outbound Tourism: A Study of Saudi Tourist. The University of Glasglow, School of Business and Management. 
Ali-Knight, J., (2000), In Search of the Grape: Towards Building a Motivational Framework for International Tourists to Australia, In: M. Robinson, P. Long, N. Evans, R. Sharpley, and J. Swarbrooke (Eds.), Motivation Behaviour and Tourist Types: Reflection on International Tourism. (pp. 1-14), (UK: Business Education Publishers).

Antariksa, Yodhia. (2017). $\mathrm{http}: / /$ strategimanajemen.net/2017/1 0/23/ranking-10-besar-penyumbangdevisa-dollar-ke-indonesia/ accessed on September $25^{\text {th }}, 2018$.

Baloglu, S., \& Uysal, M. (1996). Market segments of push and pull motivations: a canonical correlation approach. International Journal of Contemporary Hospitality Management, 8(3), 32e38.

Caber. M dan Albayrak. T., (2016). Push or Pull? Identifying rock climbing tourist' motivation. Tourism Management. Volume 55, August 2016. Pages 74-84.

Cha, S., McCcleary, K. W., and Uysal, M., (1995), 'Travel Motivations of Japanese Overseas Travelers: A Factor-Cluster Segmentation Approach', Journal of Travel Research, 34, 33-39.

Chen, Li-Ju., Chen, Wei-Peng. (2015). Push-pull factors in international birders' travel. Tourism Management 48, 417.

Cohen, E., (1972), 'Towards Sociology of International Tourism', Social Research, 6, 18-35.

Crompton, J. L., (1979), 'Motivations for pleasure vacations', Annals of tourism research, 6, 408-24.
Dann, G. (1977). Anomie, egoenhancement and tourism. Annals of Tourism Research, 4(4), 184e194.

Echols, John M. dan Hassan Shadily. (2003). Kamus Inggris-Indonesia. Jakarta: P.T. Gramedia Pustaka Utama.

Fahdeli, Chafid. (1995). Dasar-Dasar Manajemen Kepariwisataan Alam. Liberty. Yogyakarta.

Giddy dan Webb. 2016. The Influence of The Environment On Adventure Tourism: From Motivation to Experiences, Current Issues In Tourism. Routledge Tailor and Francis Group.

Hermansyah, Danu dan Waluya, Bagja. (2012). Analisis Faktor-Faktor Pendorong Motivasi Wisatawan Nusantara Terhadap Keputusan Berkunjung Ke Kebun Raya Bogor, 2(1), 245-268. Retrieved from Tourism and Hospitality Essentials (THE) Journal.

Hermantoro. (2015). Kepariwisataan, Destinasi Wisata, Produk Wisata. Aditri Publishig. Depok-Jawa Barat.

Ingkadijaya, R. (2018). Family Tourist - is Different Motive, Different Choice of Tourist Activity?. E-Journal Of Tourism, $72-84$. doi:10.24922/eot.v5i2.41704.

Jang S. \& Cai, L. (2002). 'Travel Motivations and Destination Choice: A Study of British Outbound Market', Journal of Travel \& Tourism Marketing, 13,111- 133.

Kim, K., Oh, L., \& Jogaratnam, G., (2007) 'college student travel: A revised model of push motives', Journal of Vacation Marketing, 13 (1), 73-85. 
Kim, S. S., Lee, C. K., \& Klenosky, D. B. (2003). The influence of push and pull factors at Korean national parks. Tourism Management, 24(2), $169 \mathrm{e} 180$.

Klenosky, D. B. (2002). The "pull" of tourism destinations: a means-end investigation. Journal of Travel Research, 40(4), 385e395.

Kotler \& Amstrong. (2009). Prinsip prinsip Pemasaran, Edisi 12, Jilid 2. Jakarta. Erlangga.

Kotler \& Keller (2014). Marketing Management. 15 Edition, Prentice Hall, Saddle River.

Kozak \& Decrop. (2009). Handbook of Tourist Behaviour: Theory and Practice. Routledge.

Kuhn, P., Bendesa, K., Wiranatha, A., \& Oka Suryawardani, I. (2019). Does Motivation and Trust Important for Tourists' Loyalties? A Quantitative Perspective from Golf Tourism in Bali of Indonesia.E-Journal of Tourism, 88-101. doi:10.24922/eot.v6i1.47481.

Oh, H., Uysal, M. and Weaver, P. A, (1995), 'Product Bundles and Market Segments Based on Travel Motivations: a Canonical Correlation Approach', International Journal of Hospitality Management, 14(2), 123137.

Passenger Exit Survey (PES) Kemenpar, (2016) www. Kemenpar.go.id/userfiles/indografis pes2016.pdf accessed on September 20, 2018.
Prayag, G., \& Hosany, S. (2014). When Middle East meets West: understanding the motives and perceptions of young tourists from United Arab Emirates. Tourism Management, $\quad 40, \quad 35 \mathrm{e} 45$. http://dx.doi.org/10.1016/j.tourman.2 013. 05.003.

Prayag.G dan Ryan. C., (2011). The relationship between the 'push'and 'pull'factors of a tourist destination: The role of nationality-an analytical qualitative research approach.

Pritchard, R.D \& Ashwood, E.L. (2008). Managing Motivation: A Manager's Guide to Diangnosing and Improving Motivation. New York : Routledge.

Sari, D. (2017). Peranan Wisatawan Domestik Dalam Wisata Menyelam Di Indonesia. Bogor Hospitality Journal. Vol.1 No.1 p.1-10.

Sari, D. (2017). The Process of Making Tempe Benguk as Tourist Attraction in Kulon Progo Yogyakarta. EJournal of Tourism,, 78-84. doi:10.24922/eot.v4i2.36399

Seebaluck et al. (2013). An Evaluation of Tourists' Travel Motivations: Case of Mauritius. Blobal Conference on Business and Finance Proceedings Vol 8(2) p. 146-153.

Spillane, James J.(1997). Pariwisata Indonesia. Kanisiua. Yogyakarta.

Sudaryanti, et al. (2015). Analisis FaktorFaktor Yang Mempengaruhi Motivasi Wisatawan Dalam Melakukan Wisata Heritage Di Kawasan Braga Kota Bandung. Jurnal Manajemen Resort \& Leisure. Vol 12, No.1.

Swarbrooke dan Horner. (2007). Consumer behaviour in tourism. Burlington, MA: ButterworthHeinemann. London. 
Turnbull Desna $\mathrm{R}$ and an Uysal, $\mathrm{M}$. (1995). An Exploratory Study of German Visitors to the Caribbean. https://doi.org/10.1300/J073v04n02_ 07.

Uysal, M., and Jurwski, C., (1994), 'an empirical Testing of the Push and Pull Factors of Tourists Motivations', Annals of Tourism Research, 21 (4), 844-846

Wandari, Lita Ayu, Srikandi, Kumadji \& Andriani, Kusumawati. (2014). Pengaruh City Branding "Shining Batu" Terhadap City Image Dan Keputusan Berkunjung Wisatawan Ke Kota Batu Tahun 2014. Jurnal Administrasi Bisnis.

Wibisono, Jeffry. (2013). http://jeffreywibisono.com/motivasiberwisata-dan-faktor-penariknya/. Accesed on September 20, 2018

Yiamjanya. S dan Wongleedee. K., (2014) - International Tourists' Travel Motivation by Push-Pull Factors and the Decision Making for Selecting Thailand as Destination Choice. World Academy of Science, Engineering and Technology International Journal of Social, Behavioral, Educational, Economic, Business and Industrial Engineering Vol:8, No:5.1

Yuan, S., and McDonald, C., (1990), 'Motivational Determinates of International Pleasure Travel', Journal Tourism Research, 29, 4244.

http://www.oicstatcom.org/imgs/news/File /1050-presentations/sudan.pdf

https://www.stat.fi/meta/kas/maahsuuntma tk_en.html 